\title{
Acquisition of reading and writing skills - comparative approach between the Montessori method and the traditional educational system
}

\author{
Rafila-Elisabeta Ilovan
}




\title{
Acquisition of reading and writing skills - comparative approach between the Montessori method and the traditional educational system
}

\author{
Rafila-Elisabeta Ilovan ${ }^{{ }^{*}}$ \\ ${ }^{a}$ Doctoral School "Education, Reflection, Development", Babeş-Bolyai University, 7 Sindicatelor Street, 400029, Cluj-Napoca, Romania \\ *Corresponding author: rafy_tupcil92@yahoo.com
}

\section{Abstract}

Keywords:

Reading and writing skills, alternative education, The Montessori method;
The microstudy presented is a psycho-pedagogical experiment, which consists in applying the Montessori-specific experimental factor to a group of pre-school children in the traditional system. The investigative approach is based on a comparative study, the results obtained being interpreted from both a quantitative and a qualitative point of view. In this paper we started from the premise that Montessori strategies foster the acquisition of reading and writing skills at pre-school age. The general objectives of the investigation are the introduction into the traditional experimental system of alternative methods of acquiring reading-writing skills specific to the Montessori system and the study of the Montessori system for the acquisition of reading and writing skills in methodical terms and from the point of view of the results obtained by applying these strategies.

\section{Zusammenfasung}

\section{Schlüsselworte:}

Lese- und

Schreibfähigkeiten,

alternative Ausbildung,

Die Montessori-Methode;
Die vorgelegte Mikrostudie ist ein psycho-pädagogisches Experiment, bei dem der Montessori-spezifische experimentelle Faktor auf eine Gruppe von Vorschulkindern im traditionellen System angewendet wurde. Der untersuchende Ansatz basiert auf vergleichenden Studien. In diesem Beitrag gingen wir von der Prämisse aus, dass Montessori-Strategien den Erwerb von Lese- und Schreibfähigkeiten im Vorschulalter fördern. Die allgemeinen Ziele der Untersuchung sind die Einführung alternativer Methoden für das Erlernen von Lese- und Schreibfähigkeiten für das Montessori-System in das traditionelle experimentelle System und das Studium des Montessori-Systems für den Erwerb von Lese- und Schreibfähigkeiten in methodischer Hinsicht der Ergebnisse, die durch die Anwendung dieser Strategien erzielt wurden.

\section{Introduction}

The school must be transformed into a place where the child should feel good and be eager to learn. School must be an institution capable of opening perspectives and stimulating creativity, a place where students can freely undertake the cultural and moral experiences necessary for their maturity process. In order to be successful, its construction must be based on the premise that any educational activity is based on the psycho-pedagogical knowledge of the subjects undergoing such intervention. The quality of the educational process depends entirely on the psychological abilities of those who do it.

\section{Theoretical foundation}

In the Pedagogical Dictionary (Schaub \& Zenke, 2001), the term "alternative education" has the following definition: "the activity which takes place in school institutions, according to objectives, organization, content, forms of teaching and learning, tools, school life and parents activity, with total or partial deviation from the unitary characteristics of the school state and which offers another form of training and education."

In Pedagogical Lexicon, Mircea Ştefan attributes to the alternatives the following defining characteristics: forms to solve in different ways a certain pedagogical problem presenting educational advantages but also risks, different forms of the school organization officialized by the Law of Education, the multitude of currents, cooperative or contradictory, consulting alternative systems that are compatible with each other.

The education method proposed by Maria Montessori is based on respect for the freedom of the child in an organized environment rich in stimuli chosen according to her natural interests and desires (Montessori, 1922). 
The Montessori method focuses on the use of multiple channels to receive information. Children learn to write before they learn to read, using all their senses: touching, seeing, hearing. Maria Montessori observed that there is no absolute simultaneity between the act of reading and writing, the pre-reading writing.

Maria Montessori set up a complex writing teaching mechanism in two steps Montessori, 1977. The first step - the child learns through games and practical exercises how to hold the writing tool without getting tired. Then, the child learns how to draw the form of each letter. Only in the second stage does the child learn to read the words.

\section{Research methodology}

The didactical experimental research performed was based on a methodology system consisting of: the psychopedagogical experiment, observation, research method of curricular documents and other school documents, pedagogical knowledge tests (Bocoş, 2007).

The general hypothesis:

Considering these innovative tendencies from the Romanian education system, we have formulated the following hypothesis: the early use of Montessori-specific strategies in the traditional system leads to earlier acquisition of reading and writing abilities, in shorter time, and reduces confusion between sounds, letters or sounds and letters within the words.

The study was organized in three stages: preexperimental stage, experimental intervention stage and post-experimental stage.

In performing the pedagogical research, we formulated the following research variables:

Table no. 1. Research variables

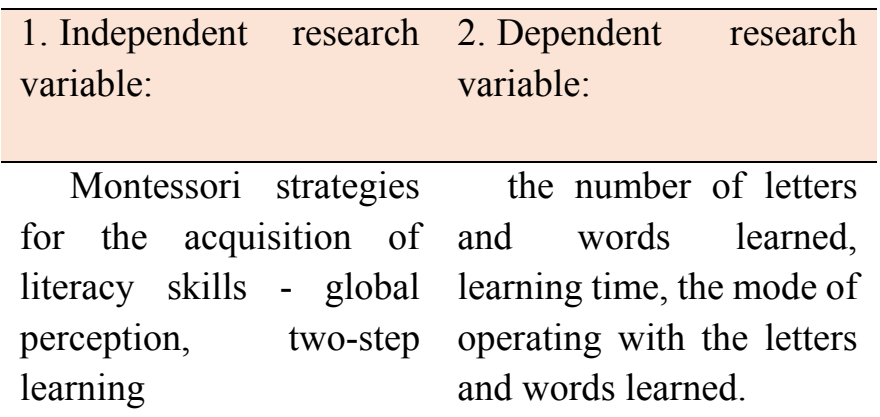

\section{The results obtained and discussions/ the analysis of the results}

\section{Initial test:}

Sample 1 - Recognizing and Reading the Suggested Letters to the Content.

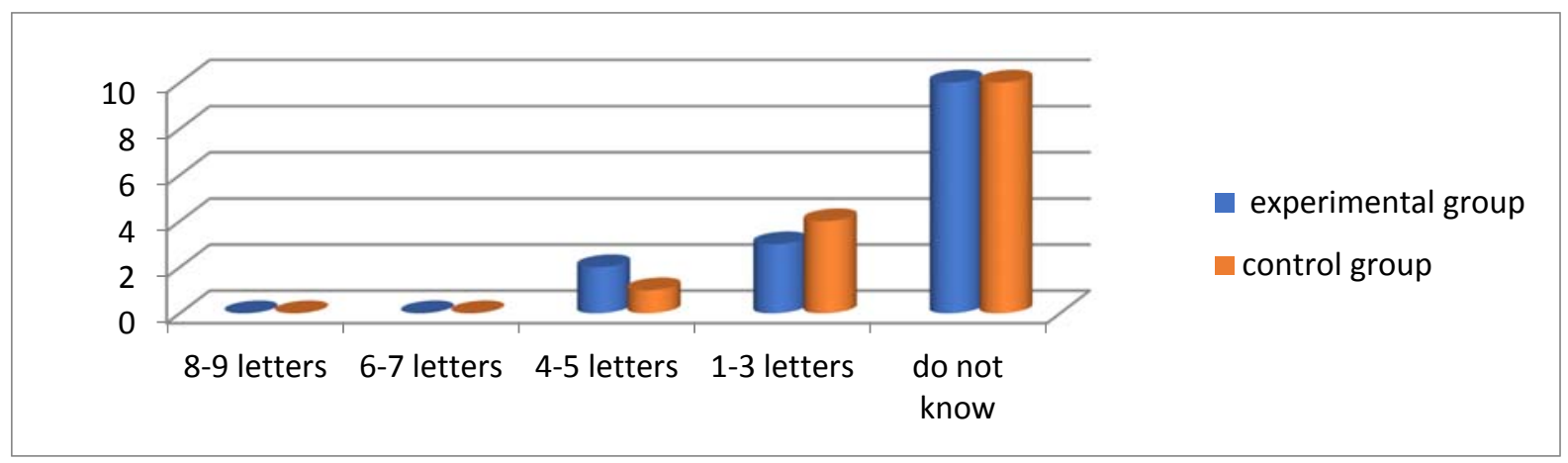

Figure no. 1. Number of known letters

$\mathrm{A}, \mathrm{M}$, and $\mathrm{T}$ are the known letters. We notice that two-thirds of children do not know letters. 
Sample 2 - reading the words.

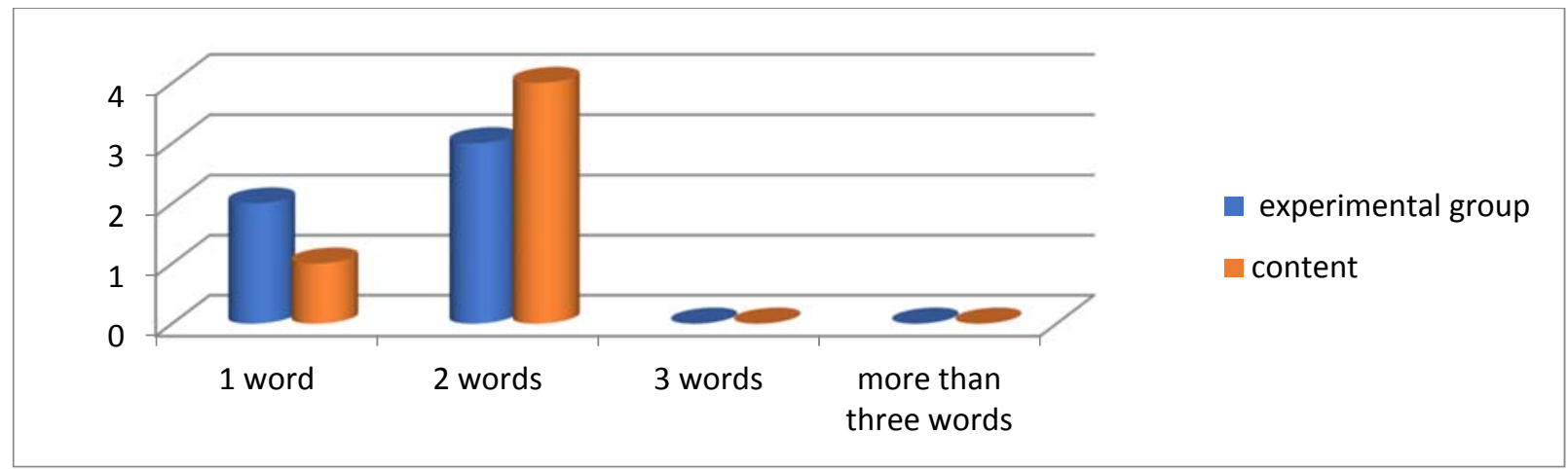

Figure no. 2. The number of words read

The words read are MAMA (mother) and TATA (father), words that children learn at home, from parents, brothers, or relatives.

Sample 3 - Modeling / Drawing a Known / Unknown Letter.

At this test, $80 \%$. of children in each group manage to model or draw a letter.

\section{Final Test:}

Sample 1 - writing letters and words

Choose the right letters and write the word written on the token (RAC, PARA) on the mat

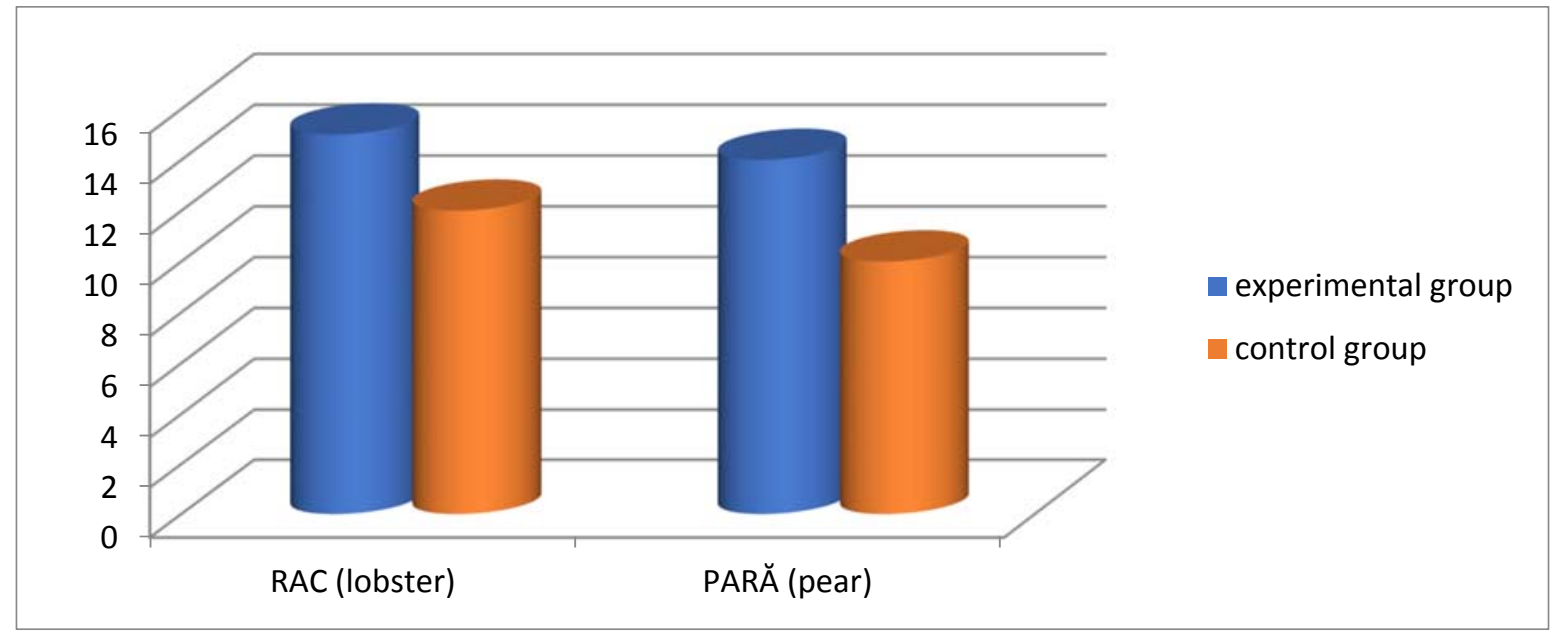

Figure no. 3. Writing by pattern

We note that in the experimental group all children write the monosyllabic word and 10 children can write the disyllabic one, while the group of children who manage to write correctly is smaller (14 for the monosyllabic word and 8 for the disyllabic word). 
Sample 2 - reading letters and words

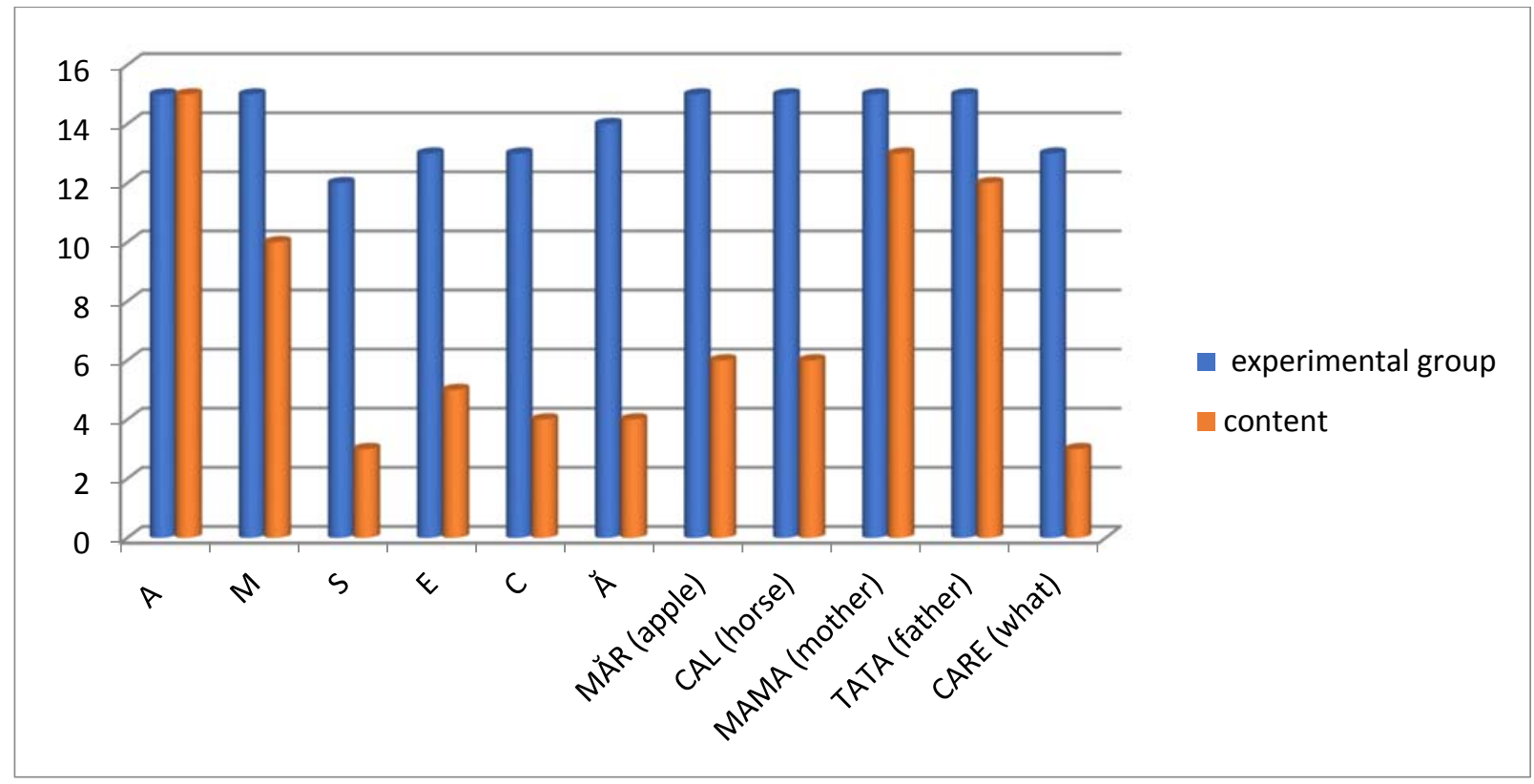

Figure no. 4. Reading

The results are better, this time at the experimental group. Also, children in the experimental group clearly distinguish letters A and $\breve{A}$ and read new words, composed of known letters. The progress has come as a result of the compositional exercises done after recognition and reproduction by modeling or drawing of the graphic sign (letter). Note that the distinction between $\mathrm{L}$ and $\mathrm{R}$ is made more easily and clearly in the experimental sample.

\section{Sample 3 - Composition and word writing}

Choose the right letters and write the word on the token (bed, hoe).

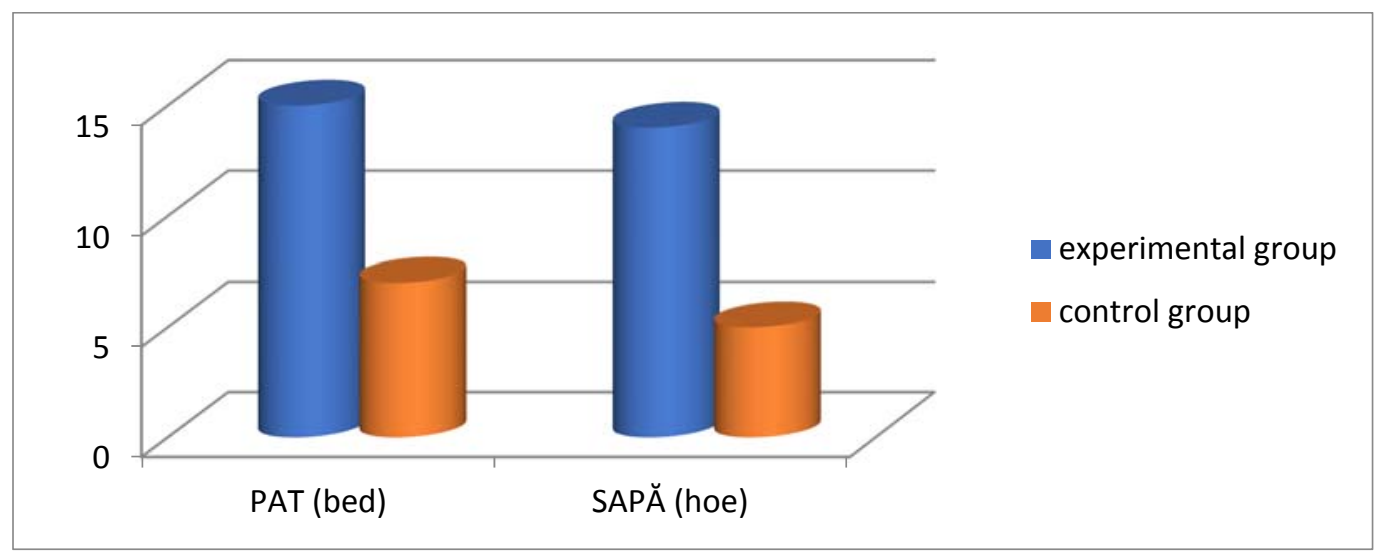

Figure no. 6. Writing the illustrated words

In the experimental group we observe $100 \%$ correct writing for the monosyllabic word and 14 of 15 children write correctly the disyllabic word, while only 8 and 5 children out of 15 manage to do it correctly.

\section{Conclusions}

Language development is closely related to the concept building process. The findings of the present research are based on practical examples from children's life experience, the way they develop their progressive language and gradually begin to grasp the mathematical 
ideas contained in language expressions, by starting from concrete object activities.

The strategies proposed in the paper can be tailored to any desirable outcome of any type of activity and of any learning sequence, provided that in the design stages the strategies (methodological and didactic materials) are best suited to the combination of elements of content and entertainment, and tasks are formulated in a clear, attractive and motivating way.

After processing the statistical data, evidence reveal the progress registered in the experimental class. Therefore, the implementation of this practicalapplicative research with improvement and developmental elements, in which the independent variable was the set of strategies and techniques specific to the Montessori system, proved effective. Thus, we can say that the independent variable has made a positive contribution to the improvement of the quality and efficiency of didactic approaches, confirming the research hypothesis.

\section{Authors note:}

Rafila-Elisabeta Ilovan is currently a teacher at Mihai Eminescu School Năsăud, Bistriţa-Năsăud County, Romania and doctoral student at Babeș-Bolyai University. Her fields of research aim to provide students information and support. She is also interested in finding the children's learning needs and giving them all the necessary resources.

\section{References}

Bocoş, M. (2007). Teoria şi practica cercetării pedagogice. Cluj-Napoca: Casa Cărţii de Ştiinţă.

Montessori, M. (1977). Descoperirea copilului, București: Editura Didactică și Pedagogică.

Montessori, M. (1922). Metoda pedagogiei științifice aplicată la educația copiilor mici. București: Editura Cartea Românească.

Schaub, H., Zenke K.-G. (2001). Dicționar de pedagogie. Iași: Editura Polirom.

Ștefan, M. (2007). Lexicon de pedagogie. București: Editura Aramis. 